\title{
Determination of In Vitro Antioxidant Properties, Anti-inflammatory Effects and A-Amylase Inhibition of Purple Sea Urchin Extract of Echinometra mathaei from the Persian Gulf
}

\author{
Soolmaz Soleimani, ${ }^{1}$ Soheila Moein, ${ }^{2,3,}{ }^{*}$ Morteza Yousefzadi, ${ }^{1}$ and Narges Amrollahi Bioki ${ }^{1}$ \\ ${ }^{1}$ Department of Marine Biology, Faculty of Marine Sciences and Technology, Hormozgan University, Bandar Abbas, IR Iran \\ ${ }^{2}$ Molecular Medicine Research Center, Hormozgan University of Medical Sciences, Bandar Abbas, IR Iran \\ ${ }^{3}$ Department of Biochemistry, Faculty of Medicine, Hormozgan University of Medical Sciences, Bandar Abbas, IR Iran \\ "Corresponding author: Soheila Moein, Department of Biochemistry, Faculty of Medicine, Hormozgan University of Medical Sciences, Bandar Abbas, IR Iran. Tel: +98-9171127539, \\ E-mail: shoeila_9@yahoo.com
}

Received 2016 February 01; Revised 2016 September 29; Accepted 2016 October 31.

\begin{abstract}
Background: Sea urchins contain high values of antioxidant substances such as polyphenols.

Objectives: In the present study, the antioxidant activities, $\alpha$-amylase inhibition, anti-inflammatory activity and the amounts of phenols and flavonoids of purple sea urchin Echinometra mathaei tissues obtained from Persian Gulf were examined.

Methods: In December 2012, the purple sea urchin E. mathaei used for this study was harvested in the intertidal zone of Qeshm Island, Hormozgan Province, Iran. In the experimental design, extract isolation of different tissues of sea urchin such as spines, shells, gonads and Aristotle's lantern was performed with the application of n-hexane, ethyl acetate and methanol solvents. Antioxidant properties of the samples were evaluated using different antioxidant tests such as total antioxidant capacity (TAC) and reducing power. The anti-diabetic and anti-inflammatory effects of samples were examined by inhibition of $\alpha$-amylase and retardation of serum albumin denaturation, respectively.

Results: With respect to antioxidant properties, the methanol extract of shell containing $40 \mu \mathrm{g} / \mathrm{mL}$ concentration possessed the maximum reducing power $(\mathrm{OD}=0.475 \pm 0.0049$ and, ethyl acetate extract of Aristotle's lantern at $1 \mathrm{mg} / \mathrm{mL}$ concentration presented the highest TAC $(\mathrm{OD}=0.439 \pm 0.0018)$. The $\mathrm{n}$-hexane extract of gonad at a concentration of $1 \mathrm{mg} / \mathrm{mL}$ revealed the highest $\alpha$-amylase inhibition $(84.7 \pm 2.92 \%)$. The ethyl acetate extract of Aristotle's lantern at $20 \mu \mathrm{g} / \mathrm{mL}$ concentration possessed the highest anti-inflammatory property $(69.78 \pm 1.61 \mu \mathrm{g} / \mathrm{mL})$. In biochemical analysis, the methanol extract of spine and ethyl acetate extract of Aristotle' lantern had the highest phenolic $(0.33 \pm 0.017 \mathrm{mg} / \mathrm{g})$ and flavonoid compounds $(24.6 \pm 0.72 \mathrm{mg} / \mathrm{g})$, respectively.

Conclusions: The obtained results revealed that sea urchin extracts could be used in pharmaceutical industries. Furthermore, its application in food industries as a supplementary food can be of great value.
\end{abstract}

Keywords: Antioxidant Effects, Sea Urchins, Phenolic Compounds, Anti-Inflammatory Effects, Inhibition of $\alpha$-Amylase

\section{Background}

Sea urchins belong to the group of echinoderm marine invertebrates pertaining to sea star, brittle sea star and sea cucumbers. They have orbicular bodies coated with a strict shell and thoroughly covered with many sharp spines (1). The edible part of the sea urchin, i.e. gonad, is half-moon shaped, yellow-orange in color and constitutes $10 \%$ of the total weight (2). Gonad has the highest levels of free amino acids, i.e. up to 10/100 g of proteins (3). The taste of sea urchin roe is similar to that of caviar and oysters. Furthermore, it can be consumed either as raw or fermented products; that is why sea urchins are usually consumed by Japanese, French and also South and North Americans (1). The mentioned species is a severe grazer on seaweeds, especially on brown algae such as Laminaria species and is thus expected to accumulate a number of antioxidant compounds such as carotenoids and polyphenols (4).

These natural antioxidants capable of scavenging the free radicals play a significant role in prevention of vascular diseases and some types of cancer (5). Free radicals, which have one or more unpaired electrons in their outer orbital, consist of superoxide anion $\left(\mathrm{O}_{2} \bullet^{-}\right)$, alkoxy $(\mathrm{RO} \bullet)$, peroxyl (ROO•), hydroxyl ( $\mathrm{HO} \bullet$ ) and nitric oxide. Oxygencentred free radicals are, sometimes known as reactive oxygen species (ROS) (6), which attack macromolecules such as lipids, proteins, enzymes, DNA and RNA (7). Scavenging of ROS leads to a reduction of oxidative stress of organisms and prevents a number of chronic and degenerative diseases such as aging, stroke, diabetes mellitus, cancer, cardiovascular and neurodegenerative complications (8). Hence, the antioxidants capable of scavenging ROS are expected to improve these disorders (9).

Examining the evolution of human diets reveals that 
in the Paleolithic age humans consumed a lot of antioxidants derived from the plants (10). Over the past decades, human nutrition in industrial countries had changed towards fast-food nutrition, which is rich in lipids and poor in antioxidant compounds. Increasing of pro-oxidant compounds appears to lead to increased risk of physiological disturbances. According to the nutritionists and physicians' health recommendations, people must increase their intakes of fruits and vegetables to provide their daily dietary nutritional antioxidants. In this regard, seafood can be considered as part of a healthy diet. Seafood species such as mussels, scallops, crabs and sea urchins are seldom considered as sources of antioxidants (4). A key difference between dietary supply and physiological needs may be in the provided antioxidant nutrients. Hence, consumption of antioxidants is essential as humans are exposed to a diverse array of oxidants (10).

\section{Objectives}

In the present study, the antioxidant activities, $\alpha$ amylase inhibition, anti-inflammatory property and total phenols and flavonoids of purple sea urchin Echinometra mathaei tissues were evaluated.

\section{Methods}

\subsection{Materials}

Butylated hydroxyltoluene (BHT), $\alpha$-amylase and bovine serum albumin (BSA) were purchased from SigmaAldrich. All the other reagents were obtained from Merck Chemical Co. and all the chemicals used in the experiments were of analytical grade.

\subsection{Collection of Sea Urchin and Preparation of Extracts}

In December 2012, the purple sea urchin E. mathaei was harvested in the intertidal zone of Qeshm Island, Hormozgan province, Iran. Samples were collected and immediately transported to the laboratory and gently rinsed with filtered seawater. After dissection phase, the spines, shells, gonads and Aristotle's lantern (mouth parts) were collected, freeze-dried in dark and then ground into a powder.

Based on the increasing polarity, dried tissues of $E$. mathaei were immersed in n-hexane, ethyl acetate and methanol (1:3 w/v), respectively. Extracts were obtained by cold percolation and concentrated by a rotary evaporator at $40^{\circ} \mathrm{C}$. The concentrated extracts were dissolved in DMSO $99 \%$ and stored at $\left(-30^{\circ} \mathrm{C}\right)$ in the dark.

\subsection{Determination of Antioxidant Activities}

\subsubsection{Determination of Reducing Power}

The reducing power was determined according to the procedure described by Oyaizu. The sample solution ( 0.4 $\mathrm{mL})$, at different concentration levels $(1.25,2.5,5,10,20$ and $40 \mu \mathrm{g} / \mathrm{mL})$, was mixed in one $\mathrm{mL}$ phosphate buffer $(0.2 \mathrm{M}$, $\mathrm{pH}$ 6.6) and one $\mathrm{mL}$ potassium ferricyanide ( $1 \% \mathrm{w} / \mathrm{v})$. The mixture was incubated at $50^{\circ} \mathrm{C}$ for 20 minutes. One $\mathrm{mL}$ trichloroacetic acid (TCA, 10\% w/v) was added and mixed with $1 \mathrm{~mL}$ distilled water and $0.2 \mathrm{~mL}$ ferric chloride $(0.1 \%$ $\mathrm{w} / \mathrm{v})$. Absorbance of this mixture was recorded by a spectrophotometer at a wavelength of $700 \mathrm{~nm}$. The analyses were performed in triplicate and ascorbic acid was used as a standard (11).

\subsubsection{Determination of Total Antioxidant Capacity (TAC)}

Total antioxidant activities of the extracts were measured according to the method of Mitsuda et al. Sulfuric acid 0.6 M (7.45 mL), sodium sulphate (0.99 g) and ammonium molybdate $(1.23 \mathrm{~g})$ were mixed together in $250 \mathrm{~mL}$ distilled water and labelled as a total antioxidant capacity (TAC) solution. One-tenth $\mathrm{mL}$ of the extracts $(50,100,250$, 500 and $1000 \mu \mathrm{g} / \mathrm{mL}$ ) was dissolved in $1 \mathrm{~mL}$ of TAC solution. After 15 minutes of incubation the absorbance was read at $695 \mathrm{~nm}$. Ascorbic acid was used as a positive control (12).

\subsubsection{Determination of Total Phenolic Content}

The amounts of the phenolic compounds in the prepared extracts were determined according to the method described by Fu et al. The sample $(0.15 \mathrm{~mL}, 10 \mathrm{mg} / \mathrm{mL})$ was mixed with $0.75 \mathrm{~mL}$ Folin-Ciocalteu (diluted 1:10 with distilled water). After 3 minutes, $0.6 \mathrm{~mL}$ of saturated sodium carbonate $(7.5 \% \mathrm{w} / \mathrm{v})$ was added to the mixture. After mixing, the mixture was kept in the dark for 60 minutes, after which the absorbance was read at $765 \mathrm{~nm}$ (8). Different concentrations (0.0003-0.0024 mg/mL) of gallic acid were used as the standard curve. Total content of phenolic compounds in the extracts was calculated by the following formula:

\section{$\mathrm{C}=\mathrm{c} \cdot \mathrm{v} / \mathrm{m}^{\prime}$}

Where $\mathrm{C}$ is the total content of phenolic compounds $(\mathrm{mg} / \mathrm{g}), \mathrm{c}$ is the concentration of gallic acid specified by the standard curve $(\mathrm{mg} / \mathrm{mL}), \mathrm{v}$ is the volume of the extract $(\mathrm{mL})$, and $\mathrm{m}^{\prime}$ is the weight of pure tissue $(\mathrm{g})$.

\subsubsection{Determination of Total Flavonoid Content}

Total flavonoids were determined according to the method of Zou et al. A diluted sample $(0.5 \mathrm{~mL}, 1 \mathrm{mg} / \mathrm{mL})$ was mixed with $2 \mathrm{~mL}$ of distilled water. After 3 minutes, 0.15 mL of $5 \% \mathrm{NaNO}_{2}$ solution and $0.15 \mathrm{~mL}$ of $10 \% \mathrm{AlCl}_{3}$ solution were added and allowed to stand for 6 minutes. Then, $2 \mathrm{~mL}$ 
of $4 \% \mathrm{NaOH}$ solution was added to the mixture. Immediately, $0.2 \mathrm{~mL}$ of water was added until the final volume became $5 \mathrm{~mL}$. Next, the mixture was allowed to stand for another 15 minutes, after which the absorbance was read at $510 \mathrm{~nm}$ (6). Different concentrations (12/5, 25, 50, and 100 $\mu \mathrm{g} / \mathrm{mL}$ ) of BHT were used to draw the standard curve.

\subsection{Determination of $\alpha$-Amylase Inhibition}

The inhibition of $\alpha$-amylase was carried out with some modifications of Ademiluyi et al.'s method. In this colorimetric method, starch and 3, 5-dinitrosalicylic acid (DNSA) were used as the substrate and reagent, respectively. The standard curve of maltose, as a product, enables researchers to calculate the amounts of maltose released during $\alpha$-amylase activity. The enzyme solution (4 unit $/ \mathrm{mL}$ ) was prepared by mixing $0.001 \mathrm{~g}$ of porcine pancreatic $\alpha$-amylase (EC 3.2.1.1) in sodium phosphate buffer ( $\mathrm{pH}=6.9,20 \mathrm{mM})$, which had $6.7 \mathrm{mM}$ sodium chloride. The extracts were dissolved in DMSO and the extracted starch solution was mixed. The reagent (DNSA) solution possessed $96 \mathrm{mM}$ 3, 5-dinitrosalicylic acid (20 mL) and 5.31 $\mathrm{M}$ potassium tartrate sodium in $2 \mathrm{M}$ sodium hydroxide ( 8 $\mathrm{mL}$ ) and deionized water (12 mL).

$0.56 \mathrm{~mL}$ of the extracted-starch solution and $0.04 \mathrm{~mL}$ enzyme were mixed in a tube and incubated at $37^{\circ} \mathrm{C}$ for 15 minutes. Next, $0.6 \mathrm{~mL}$ of the color reagent (DNSA) was added, and the test tube was placed in the water bath $\left(85^{\circ} \mathrm{C}\right)$ for 15 minutes, after which the absorbance of the samples was determined at $540 \mathrm{~nm}$ (13). Additional blanks were prepared to correct the background absorbance. The control demonstrated $100 \%$ enzyme activity and substituted extracts with DMSO. One unit of the enzyme activity was defined as the amount of required enzyme to release one micromole of maltose from starch per minute. Acarbose was used as a positive control. All tests were performed in triplicate. The inhibition percentage of $\alpha$ amylase was assessed by the following formula:

$$
\begin{aligned}
& \mathrm{I}_{\alpha \text {-amylase }} \%=\left(\left(\Delta \mathrm{A}_{\text {Control }}-\Delta \mathrm{A}_{\text {sample }}\right) / \Delta \mathrm{A}_{\text {control }}\right) \times 100 \\
& \Delta \mathrm{A}_{\text {control }}=\mathrm{A}_{\text {test }}-\mathrm{A}_{\text {blank }} \\
& \Delta \mathrm{A}_{\text {sample }}=\mathrm{A}_{\text {test }}-\mathrm{A}_{\text {blank }}
\end{aligned}
$$

\subsection{Determination of Anti-Inflammatory Effect by Inhibition of Protein Denaturation}

The test was performed by modifying the method described by Mizushima et al. The reaction mixture contained $0.05 \mathrm{~mL}$ of different extracts at various concentrations $(1.25,2.5,5,10$ and $20 \mu \mathrm{g} / \mathrm{mL})$ and $0.45 \mathrm{~mL}$ of the bovine serum albumin (BSA, $0.1 \%, \mathrm{pH}=6.3$ ). The mixture was incubated at $37^{\circ} \mathrm{C}$ for 20 minutes and then incubated at $57^{\circ} \mathrm{C}$ for 20 minutes. After cooling the mixture, the turbidity was measured by spectrophotometer at $660 \mathrm{~nm}$ (14).
The percentage inhibition of protein denaturation was calculated as follows:

The percentage inhibition $=\left(\left(A-A_{s}\right) / A\right) \times 100$

Where $A$ is the absorbance of the control, and As is the absorbance of reaction solution. Aspirin was used as a positive control.

\subsection{Statistical Analysis}

The data was expressed as the mean \pm SD of three replicates. Analysis was performed using SPSS 19 and Excel 2010. One-way analysis of variance (ANOVA) and Duncan's new multiple-rang test were used to determine the possible differences amongst the means. P values $\leq 0.05$ were considered as significant differences.

\section{Results}

Reducing power of different extracts of sea urchin is presented in Figure $1 \mathrm{~A} \mathrm{~N}$-hexane extract of gonad, methanol extract of shell and ethyl acetate extracts of spine and Aristotle's lantern revealed the highest reducing power (Figure 1A). Significant differences were observed at $\mathrm{P}<0.05$.

In comparison with ascorbic acid as a standard, the mentioned extracts could reduce high concentrations of ferric ions. It was observed that methanol extract of the shell at $40 \mu \mathrm{g} / \mathrm{mL}$ possessed the maximum reducing power, which was more than that of ascorbic acid as a standard. Ascorbic acid had the minimum reducing power at 2.5 and $1.25 \mu \mathrm{g} / \mathrm{mL}$. Significant differences were observed at $\mathrm{P}<0.05$.

Total antioxidant capacities of different extracts of sea urchin are provided in Figure 1B. Generally, identical to ascorbic acid as a standard, the presented extracts had high total antioxidant capacities. N-hexane extracts of gonad and spine, methanol extract of shell and ethyl acetate extract of Aristotle's lantern revealed the highest total antioxidant capacities (Figure 1B). Significant differences were observed at $\mathrm{P}<0.05$.

Ethyl acetate extract of Aristotle's lantern at $1 \mathrm{mg} / \mathrm{mL}$ had more total antioxidant capacity than ascorbic acid as a standard (Figure 1B). Ethyl acetate extract of Aristotle's lantern showed the lowest total antioxidant capacity. Significant differences were observed at $\mathrm{P}<0.05$. It can be stated that total antioxidant capacity depends on the concentrations of sea urchin extracts.

Total phenolic contents of sea urchin were determined using the Folin-Ciocalteu reagent, which relying on the transfer of electrons from phenolic compounds to the Folin-Ciocalteu reagent in the alkaline medium. This technique is an applicable method, which is used widely (8). Table 1 presents total phenolic contents, which varied from 
Figure 1. A, Extracts of Echinometra matheai, Which Possessed More Reducing Power, Compared With Vit C as a Standard; B, Extracts of Echinometra matheai, Which Possessed More Total Antioxidant Capacities, Compared With Vit C as a Standard

A

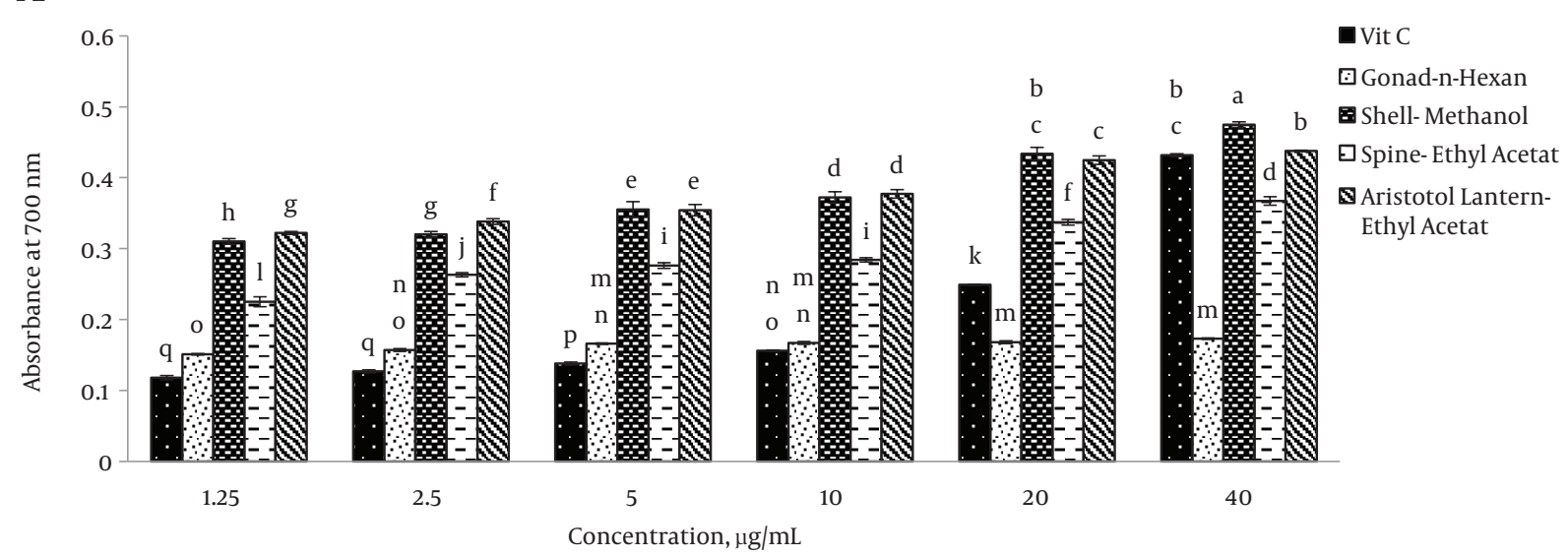

B

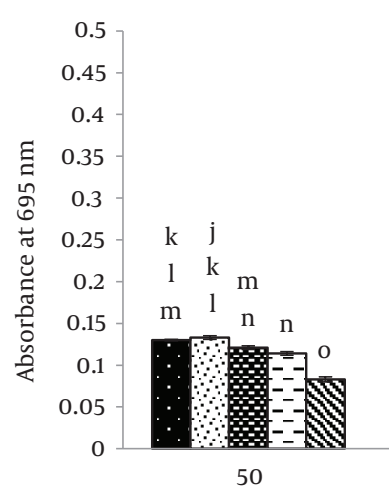

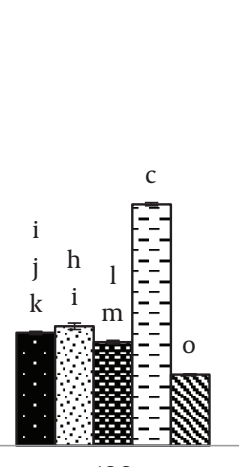

100

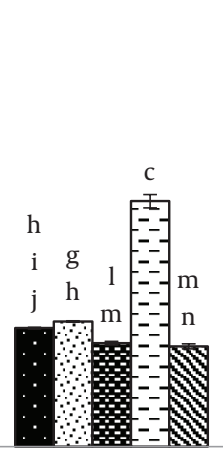

250

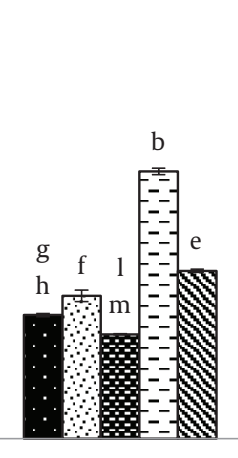

500

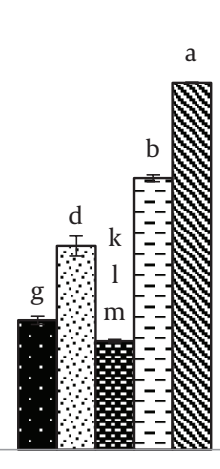

1000 a vit C

ĐGonad-n-Hexan

옹 Shell-Methanol

$\square$ Spine- n-Hexan

Aristotol LanternEthyl Acetat

Concentration, $\mu \mathrm{g} / \mathrm{mL}$

Significant differences are indicated by different letters as determined by Duncan's Post-Hok multiple comparison $(\mathrm{P}<0.05)$.

$0.0044 \pm 0.0003 \mathrm{mg} / \mathrm{g}$ (methanol extract of gonad) to $0.3256 \pm 0.0171 \mathrm{mg} / \mathrm{g}$ (methanol extract of spine). As Table 1 presents total flavonoid contents varied from $0.47 \pm 0.27$ $\mathrm{mg} / \mathrm{g}$ (ethyl acetate extract of shell) to $24.62 \pm 0.72 \mathrm{mg} / \mathrm{g}$ (ethyl acetate extract of Aristotle's lantern).

In this study, porcine pancreatic $\alpha$-amylase was used to evaluate the anti-diabetic properties of extracts at different concentrations. A-amylase inhibition at different concentrations of sea urchin extracts ( 1 and $2 \mathrm{mg} / \mathrm{mL}$ ) was determined. N-hexane extract of the gonad (84.7 \pm 2.9 ), methanol extract of the shell $(74.7 \pm 0.64)$ and n-hexane extract of the spine showed the maximum inhibition of $\alpha$-amylase, respectively (Figure 2). Significant differences were observed at $\mathrm{P}<0.05$.

The results showed that, $n$-hexane extract of the gonad at $1 \mathrm{mg} / \mathrm{mL}$ substrate possessed the highest $\alpha$-amylase in- hibition. At $2 \mathrm{mg} / \mathrm{mL}$ concentration of the substrate, ethyl acetate extract of Aristotle's lantern revealed the lowest $\alpha$ amylase inhibition (Figure 2). Significant differences were observed at $\mathrm{P}<0.05$.

Different extracts of sea urchin tissues exhibited significant anti-inflammatory properties at different concentrations. Generally, these extracts had similar antiinflammatory properties like that of aspirin. The lower IC50 indicated the higher anti-inflammatory ability (Table 2). The highest anti-inflammatory properties were detected in the methanol extract of gonad, ethyl acetate extract of shell and Aristotle's lantern as well as n-hexane extracts of spine. Methanol extract of gonad at $1.25 \mu \mathrm{g} / \mathrm{mL}$ concentration showed inflammatory effects identical to that of aspirin (Figure 3).

The ethyl acetate extract of Aristotle's lantern at 
Table 1. The Amounts of Total Phenols and Flavonoids in Extracts of Sea Urchin $E$. mathaei $^{\mathrm{a}}$

\begin{tabular}{|lcc|}
\hline Sample & $\begin{array}{c}\text { Phenolic Content, } \\
\text { mg GAE/g }\end{array}$ & $\begin{array}{c}\text { Flavonoid Content, } \\
\text { mg BHT/g }\end{array}$ \\
\hline $\begin{array}{l}\text { Methanol extract of } \\
\text { gonad }\end{array}$ & $0.0044 \pm 0.0003$ & - \\
\hline $\begin{array}{l}\text { Methanol extract of } \\
\text { shell }\end{array}$ & $0.1781 \pm 0.017$ & - \\
\hline $\begin{array}{l}\text { Methanol extract of } \\
\text { spine }\end{array}$ & $0.3256 \pm 0.017$ & - \\
\hline $\begin{array}{l}\text { Methanol extract of } \\
\text { aristotles lantern }\end{array}$ & $0.0227 \pm 0.001$ & - \\
\hline $\begin{array}{l}\text { Ethyl acetate extract } \\
\text { of gonad }\end{array}$ & - & $3.9 \pm 0.41$ \\
\hline $\begin{array}{l}\text { Ethyl acetate extract } \\
\text { of shell }\end{array}$ & - & $0.47 \pm 0.27$ \\
\hline $\begin{array}{l}\text { Ethyl acetate extract } \\
\text { of spine }\end{array}$ & - & $4.81 \pm 0.32$ \\
\hline $\begin{array}{l}\text { Ethyl acetate extract } \\
\text { of aristotles lantern }\end{array}$ & - & \\
\hline \begin{tabular}{l} 
a Value are expressed as mean $\pm \mathrm{SD} ;(\mathrm{n}=3)$. \\
\hline
\end{tabular} & \\
\hline
\end{tabular}

Figure 2. A-Amylase Inhibition of the Echinometra matheai Extracts

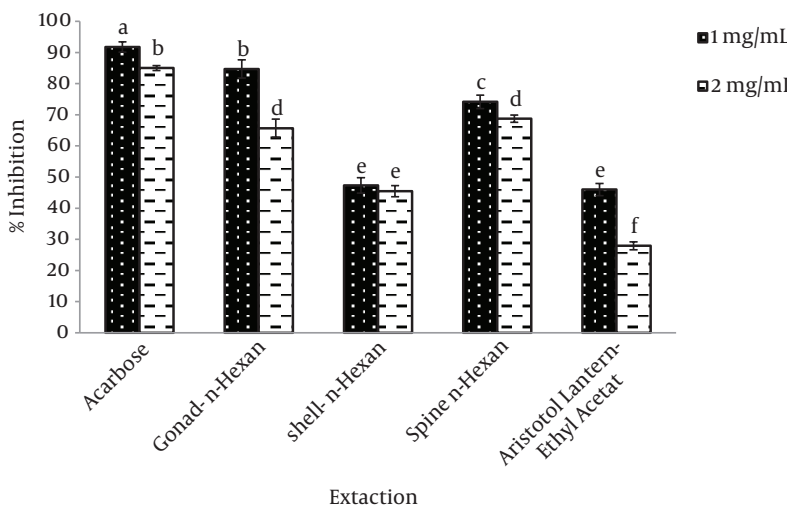

Significant differences are indicated by different letters as determined by Duncan's Post-Hok multiple comparison $(\mathrm{P}<0.05)$

$20 \mu \mathrm{g} / \mathrm{mL}$ concentration possessed the highest antiinflammatory activity similar to that of aspirin as a standard $(\mathrm{P}<0.05)$. Ethyl acetate extract of the shell revealed the lowest anti-inflammatory effect. Anti-inflammatory potential was found to increase by increasing the concentrations of sea urchin extracts, regardless of the nature of preparation.

\section{Discussion}

$\mathrm{N}$-hexane extract of gonad, methanol extract of shell and ethyl acetate extracts of spine and Aristotle's lantern
Table 2. $\mathrm{IC}_{50}$ Values $(\mu \mathrm{g} / \mathrm{mL})$ of Sea Urchin Extracts in Proteinase Inhibition Assay

\begin{tabular}{lc}
\hline Samples & $\begin{array}{c}\text { IC }_{50} \text { of Proteinase Inhibition } \\
\mu \mathrm{g} / \mathbf{m L}\end{array}$ \\
\hline Aspirin & $2.25 \pm 0.14^{\mathrm{a}}$ \\
\hline Methanol extract of gonad & $3.06 \pm 0.25^{\mathrm{b}}$ \\
\hline Methanol extract of shell & $\mathrm{NA}$ \\
\hline Methanol extract of spine & $\mathrm{NA}$ \\
\hline $\begin{array}{l}\text { Methanol extract of aristotles } \\
\text { lantern }\end{array}$ & $\mathrm{NA}$ \\
\hline $\begin{array}{l}\text { Ethyl acetate extract of gonad } \\
\text { Ethyl acetate extract of shell }\end{array}$ & $4.56 \pm 0.12^{\mathrm{b}}$ \\
\hline $\begin{array}{l}\text { Ethyl acetate extract of spine } \\
\text { Ethyl acetate extract of aristotles }\end{array}$ & $\mathrm{NA}$ \\
\hline lantern & $3.35 \pm 0.06^{\mathrm{c}}$ \\
\hline n-hexane extract of gonad & \\
\hline n-hexane extract of shell & \\
\hline n-hexane extract of spine & $2.71 \pm 0.21^{\mathrm{c}}$ \\
\hline $\begin{array}{l}\text { n-hexane extract of aristotles } \\
\text { lantern }\end{array}$ & $2.70 \pm 0.15^{\mathrm{a}, \mathrm{b}}$ \\
\hline $\begin{array}{l}\text { Abbreviation: NA, Not active. } \\
\text { a There are not any statistical differences P }>0.05 .\end{array}$ \\
$\begin{array}{l}\mathrm{b} \text { Statistical differences }(\mathrm{P}<0.05) . \\
\text { Statistical differences }(\mathrm{P}<0.05) .\end{array}$ \\
\hline
\end{tabular}

had the highest reducing power. In the biochemical analysis, the methanol extract of spine and ethyl acetate extract of Aristotle lantern had the highest phenolic and flavonoid compounds, respectively. The n-hexane extract of gonad at $1 \mathrm{mg} / \mathrm{mL}$ showed the highest $\alpha$-amylase inhibition. The ethyl acetate extract of Aristotle lantern at $20 \mu \mathrm{g} / \mathrm{mL}$ possessed the highest anti-inflammatory property.

In the present study, the antioxidant properties of different extracts of sea urchin were evaluated with consideration of reducing power, total antioxidant capacity and determination of phenolic and flavonoid compounds. The reducing power assay was used to evaluate the reduction of $\mathrm{Fe}^{+3}$ by sea urchin extracts. Due to its easy application, this method is widely used for appraisal of antioxidant capacity (8). Increasing the absorbance of the reaction mixture indicates an increase of the reducing power. In the reducing power assay, the yellow color of the test solution changes to several shades of green and blue, depending on the reducing power of each extract (5). The results of the previous studies $(5,8)$ showed that all the tested extracts could reduce iron (III). Furthermore, they reported that reducing power of the extracts depended on their concentrations. Hence, the reducing power could mainly be imputed to the bioactive compounds associated with antioxidant activity (5). Our previous study on the shell and spine pig- 


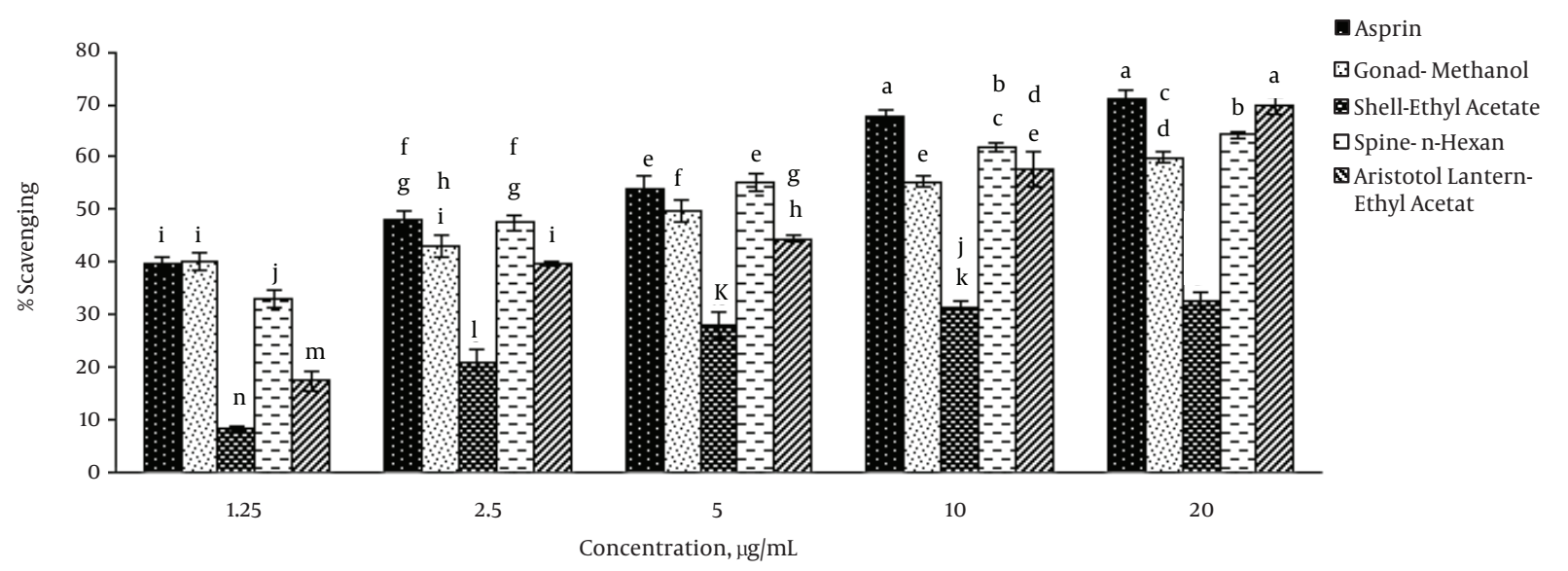

Significant differences are indicated by different letters as determined by Duncan's Post-Hook multiple comparison (P $\leq 0.05)$.

ments of purple sea urchin E. mathaei showed that reducing power of both pigments extractions (shell and spine) increased as the concentrations increased (15). Results from previous studies have shown that dicholoromethan extract of sea cucumber Holoturia leucospilota increases absorbance with increasing dose dependent manner (16).

Naturally, there are a number of antioxidant compounds that act as radical scavengers and lipid peroxidation inhibitors. Usage of natural antioxidants such ad polyphenols in general and flavonoid in particular can be considered as relevant components to reduce the risk of developing coronary heart diseases, neurological disorders and certain types of cancers (17). The obtained results showed that total phenols of purple sea urchin $E$. mathaei tissue extracts are similar to those of gonads (53 $\mathrm{mg} \mathrm{GAE} / 100 \mathrm{~g}$ ) and digestive tracts (123 mg GAE/100 g) of green sea urchin centrotus droebachiensis and shells (1.5 mg GAE/g) of red-brown sea urchin Psammechinus miliaris (18). Phenolic compounds may account for antioxidant properties such as reducing power (5), which are caused by hydroxyl groups of these molecules $(19,20)$.

Some antioxidant compounds could inhibit $\alpha$ amylase. With consideration of the mentioned point, the inhibition of $\alpha$-amylase was determined by different extracts of sea urchin in the present study. As the review of literature reveals, it is the first time that the inhibition of $\alpha$-amylase by these extracts has been reported. The results of the present study demonstrate that delayed starch hydrolysis by inhibition of $\alpha$-amylase leads to the decline of these extracts in the glucose concentration (21).

The observed mechanism of sea urchin extract exhibited its hypoglycaemic effect, which leads to decrease of postprandial blood glucose level. A-amylase inhibition may depend on the concentrations of extracts and types of bioactive compounds in these extracts (22).

Moreover, it is reported that diets rich of antioxidant compounds decrease the incidence of oxidant-linked diseases such as diabetes (23). Various studies have demonstrated that extracts with strong antioxidant activity, which inhibit free radicals such as superoxide and hydroxyl can be effective in inhibition of $\alpha$-amylase (24-26).

Over the recent years, attention has mainly been devoted to specify antioxidant and anti-inflammatory compounds due to their potential usage in treatment of several chronic and infectious diseases. Epidemiologically and tentative studies have implicated oxidative cellular damage arising as a result of an imbalance between free radicals generation and scavenging systems, which can cause cardiovascular diseases, cancer and aging (27). A number of studies reported the anti-inflammatory potentials of plants and vegetables $(14,27,28)$; however, as the literature review reveals, it is the first time that the antiinflammatory effect of sea urchin has been reported.

Recent studies have been demonstrated that many flavonoids and polyphenols remarkably contributed to the anti-inflammatory properties of many plants (28). Hence, the results of this study showed that flavonoids and polyphenols of sea urchin may possess anti-inflammatory activities.

In this study, the additive effects of antioxidant properties of gonad methanol extract, ethyl acetate extracts of shell and Aristotle's lantern and n-hexane extract of spine were observed.

The mentioned results are indicative of new sources 
of antioxidants, anti-diabetic and anti-inflammatory compounds obtained from the marine. In conclusion, the present study demonstrates that tissue extracts of sea urchin possess different bioactive compounds. From the researchers' perspective, sea urchin extract can be used as a supplement in food and pharmaceutical industries.

\section{Acknowledgments}

The authors thank Hormozgan University of Medical sciences, Bandar Abbas, Iran (grant NO. 9266).

\section{References}

1. Amarowicz R, Synowiecki J, Shahidi F. Chemical composition of shells from red (Strongylocentrotus franciscanus) and green (Strongylocentrotus droebachiensis) sea urchin. Food Chem. 2012;133(3):822-6.

2. Zhou DY, Qin L, Zhu BW, Wang XD, Tan H, Yang JF, et al. Extraction and antioxidant property of polyhydroxylated naphthoquinone pigments from spines of purple sea urchin Strongylocentrotus nudus. Food Chem. 2011;129(4):1591-7.

3. Amarowicz R, Synowiecki J, Shahidi F. Sephadex LH-20 separation of pigments from shells of red sea urchin (Strongylocentrotus franciscanus). Food Chem. 1994;51(2):227-9.

4. Mamelona J, Pelletier E, Girard-Lalancette K, Legault J, Karboune S, Kermasha S. Antioxidants in digestive tracts and gonads of green urchin (Strongylocentrotus droebachiensis). J Food Compos Analysis. 2011;24(2):179-83.

5. Ferreira ICFR, Baptista P, Vilas-Boas M, Barros L. Free-radical scavenging capacity and reducing power of wild edible mushrooms from northeast Portugal: Individual cap and stipe activity. Food Chem. 2007;100(4):1511-6.

6. Zou Y, Lu Y, Wei D. Antioxidant activity of a flavonoid-rich extract of Hypericum perforatum L. in vitro. J Agric Food Chem. 2004;52(16):5032-9. doi: 10.1021/jf049571r. [PubMed: 15291471].

7. Duan XJ, Zhang WW, Li XM, Wang BG. Evaluation of antioxidant property of extract and fractions obtained from a red alga, Polysiphonia urceolata. Food Chem. 2006;95(1):37-43.

8. Fu L, Xu BT, Xu XR, Gan RY, Zhang Y, Xia EQ, et al. Antioxidant capacities and total phenolic contents of 62 fruits. Food Chem. 2011;129(2):34550.

9. Shankarlal S, Prabu K, Natarajan E. Antimicrobial and antioxidant activity of Purple sea Urchin Shell (Salmacis virgulata L. Agassiz and Desor 1846). Am Eur J Sci Res. 2011;6(3):178-81.

10. Ratnam DV, Ankola DD, Bhardwaj V, Sahana DK, Kumar MN. Role of antioxidants in prophylaxis and therapy: A pharmaceutical perspective. J Control Release. 2006;113(3):189-207. doi: 10.1016/j.jconrel.2006.04.015. [PubMed:16790290].

11. Oyaizu M. Studies on products of browning reaction-antioxidative activities of products of browning reaction prepared from glucosamine. Japan J Nutr. 1986.

12. Mistuda H, Yuasumoto K, Iwami K. Antioxidation action of indole compounds during the autoxidation of linoleic acid. EIYO TO SHOKURYO. 1996;19:210-4.
13. Ademiluyi AO, Oboh G, Boligon AA, Athayde ML. Effect of fermented soybean condiment supplemented diet on $\alpha$-amylase and $\alpha$ glucosidase activities in Streptozotocin-induced diabetic rats. J Function Foods. 2014;9:1-9.

14. Mizushima Y, Kobayashi M. Interaction of anti-inflammatory drugs with serum proteins, especially with some biologically active proteins. J Pharm Pharmacol. 1968;20(3):169-73. [PubMed: 4385045].

15. Soleimani S, Yousefzadi M, Rezadoost H, Bioki N. Identification and antioxidant of polyhydroxylated naphthoquinone pigments from sea urchin pigments of Echinometra mathaei. Med Chem Res. 2016;25(7):1-8.

16. Soltani M, Baharara J. Antioxidant and antiprolifereative capacity of dichloromethane extract of holoturia leucospilota sea cucumber. Int J Data Min Bioinform. 2014:1-9.

17. Ashraf MA, Maah M, Yusoff I. Estimation of antioxidant phytochemicals in four different varieties of durian (Durio zibethinus murray) fruit. Middle East J Sci Res. 2010;6(5):465-71.

18. Powell C, Hughes AD, Kelly MS, Conner S, McDougall GJ. Extraction and identification of antioxidant polyhydroxynaphthoquinone pigments from the sea urchin, Psammechinus miliaris. LWT Food Sci Technol. 2014;59(1):455-60. doi: 10.1016/j.lwt.2014.05.016.

19. Kuwahara R, Hatate H, Chikami A, Murata H, Kijidani Y. Quantitative separation of antioxidant pigments in purple sea urchin shells using a reversed-phase high performance liquid chromatography. LWT Food Sci Technol. 2010;43(8):1185-90. doi:10.1016/j.lwt.2010.03.005.

20. Kuwahara R, Hatate H, Yuki T, Murata H, Tanaka R, Hama Y. Antioxidant property of polyhydroxylated naphthoquinone pigments from shells of purple sea urchin Anthocidaris crassispina. LWT Food Sci Technol. 2009;42(7):1296-300. doi:10.1016/j.lwt.2009.02.020.

21. Dewanjee S, Maiti A, Sahu R, Dua TK, Mandal V. Effective Control of Type 2 Diabetes through Antioxidant Defense by Edible Fruits of Diospyros peregrina. Evid Based Complement Alternat Med. 2011;2011:675397. doi:10.1093/ecam/nep080. [PubMed: 19584081].

22. Ponnusamy S, Ravindran R, Zinjarde S, Bhargava S, Ravi Kumar A. Evaluation of traditional Indian antidiabetic medicinal plants for human pancreatic amylase inhibitory effect in vitro. Evid Based Complement Alternat Med. 2011;2011 doi: 10.1155/2011/515647. [PubMed: 20953430].

23. Jo S, Ka E, Lee H, Apostolidis E, Jang HD, Kwon YI. Comparison of antioxidant potential and rat intestinal a-glucosidases inhibitory activities of quercetin, rutin, and isoquercetin. Int J Appl Res Nat Prod. 2009;2(4):52-60.

24. Jakus V. The role of free radicals, oxidative stress and antioxidant systems in diabetic vascular disease. Bratislavske lekarske listy. 2000;101(10):541-51.

25. Li W, Dai RJ, Yu YH, Li L, Wu CM, Luan WW, et al. Antihyperglycemic effect of Cephalotaxus sinensis leaves and GLUT-4 translocation facilitating activity of its flavonoid constituents. Biol Pharm Bull. 2007;30(6):1123-9. [PubMed: 17541165].

26. Ojewole JA. Hypoglycaemic effect of Clausena anisata (Willd) Hook methanolic root extract in rats. J Ethnopharmacol. 2002;81(2):231-7. [PubMed: 12065156].

27. Rahman MA, Islam MS. Antioxidant, antibacterial and cytotoxic effects of the phytochemicals of whole Leucas aspera extract. Asian Pac J Trop Biomed. 2013;3(4):273-9. doi: 10.1016/S2221-1691(13)60062-3. [PubMed: 23620850].

28. Sakat S, Juvekar AR, Gambhire MN. In vitro antioxidant and antiinflammatory activity of methanol extract of Oxalis corniculata Linn. Int J Pharm Pharm Sci. 2010;2(1):146-55. 